\author{
Матеріали усних доповідей \\ науково-практичної конференції \\ 3 міжнародною участю \\ «Актуальні питання ведення хворих \\ на хіміорезистентний туберкульоз: \\ міжнародний та національний досвід" \\ 13-16 вересня 2021 р., м. Київ, Україна
}

\title{
Динаміка захворюваності на туберкульоз у дітей в Україні за віком. Зміни співвідношення чутливого та лікарсько-стійкого туберкульозу
}

Білогорцева 0.І. ${ }^{1}$, Недоспасова 0.П. ${ }^{2}$, Шехтер І.Є. ${ }^{1}$, Копосова І.В. ${ }^{1}$, Сіваченко О.Є. ${ }^{1}$, Хлибова В.А. ${ }^{3}$

1. ДУ «Національний інститут фтизіатрії і пульмонології ім. Ф.Г. Яновського НАМН України», м. Київ, Україна

2. Д3 «Центр медичної статистики МОЗ України», м. Київ, Україна

3. КНП «Кіровоградський обласний фтизіопульмонологічний медичний центр Кіровоградської обласної ради», м. Кропивницький, Україна

Обґрунтування. 2020 рік характеризувався значним погіршенням у роботі системи раннього виявлення, профілактики та лікування туберкульозу (ТБ) в Україні. Безумовно, це було пов'язано з негативним впливом пандемії коронавірусної хвороби (COVID-19) на охорону здоров'я загалом і протитуберкульозні заходи зокрема, що було цілком прогнозованим. Але вкрай негативні наслідки на систему протитуберкульозної допомоги чинить останніми роками руйнування системи раннього виявлення та профілактики ТБ, перехід на примітивніші форми виявлення туберкульозної інфекції та малочи майже неконтрольоване лікування багатьох хворих.

Мета. Визначити особливості динаміки захворюваності на ТБ серед дітей і питомої ваги лікарсько-стійкого ТБ (ЛСТБ) за 2019-2020 рp.

Матеріали та методи. У роботі проведено порівняльний аналіз динаміки захворюваності на ТБ у дітей різних вікових груп за 2019-2020 рр., у тому числі на ЛСТБ. Дослідження виконано коштом держбюджету.

Результати. Згадані в обґрунтуванні причини призвели до «фантастичного» зменшення захворюваності на ТБ серед населення країни у 2020 р. порівняно з 2019 р. - на 30,4 \% (з 50,0 до 34,3 на 100 тис.). Зокрема, серед дітей віком до 14 років - на 34,8 \% (з 8,9 до 5,8 на 100 тис.), серед підлітків 15-17 років - на 27,5 \% (з 19,3 до 14,0 на 100 тис.).
Загалом захворюваність у віковій категорії 0-17 років зменшилася на 32,7 \%. Порівнянною була й динаміка захворюваності в дорослих: зменшення на 30,2 \% (з 57,7 до 43,3 на 100 тис.). Питома вага ТБ легень із бактеріовиділенням і деструкцією серед усіх уперше виявлених хворих на ТБ легень у країні за роками майже не змінилася та становила 68,3 та 68,6 \% у 2020 р. проти 44,9 та 43,3 \% у 2019 р. відповідно. Слід зазначити, що стрімке зниження захворюваності супроводжувалося значним збільшенням питомої ваги ЛСТБ. Частка ЛСТБ у дітей становила 36,7 \% від усіх випадків уперше діагностованого ТБ у дітей (у 2019 р. - 25,6 \%). Пацієнти з множинною лікарською стійкістю (МЛС), ризиком МЛС, широкою лікарською стійкістю (ШЛС), рифампіцинрезистентним ТБ (Риф-ТБ) становили 33,5 \%. Діти з латентною туберкульозною інфекцією, які потребували обстеження та лікування (крім дітей із відомих охороні здоров'я осередків ТБ), виявлялися практично лише в областях, де була збережена система раннього виявлення ТБ.

Висновки. Стрімке зниження захворюваності на ТБ в Україні пов'язане з низкою несприятливих об'єктивних і суб'єктивних причин і свідчить про значне недовиявлення хворих. Украй негативною ознакою є зростання у 2020 р. відсотка хворих дітей із ЛСТБ, особливо з МЛС, ризиком МЛС, ШЛС і Риф-ТБ на 8,0 \%. 